Egyptian

Orthodontic Journal

\title{
PROFILE CHANGES CONCURRENT WITH MANAGEMENT OF THUMB SUCKING HABIT
}

\begin{abstract}
Safaa A. Ghobashy* Nagwa A. Ghoname*
ABSTRACT:

The aim of this clinical study was to cephalometrically investigate profile changes after using a palatal crib and fixed orthodontic appliance therapy, in children with thumb sucking. Fifteen females with age ranged from 8 to 10 years were used in this study, irrespective of the molar relationship. Lateral cephalometric X-ray films were taken before and after treatment, and sixteen variables were measured and statistically analyzed using a paired $t$ - test. Before and after treatment differences were statistically significant for all variables except mandibular apical base relationship and maxillary length. Dentoalveolar changes were evidenced as retrusion and extrusion of incisors and decrease in the open bite and overjet. The dento-skeletal changes implied soft tissue changes in the form of retracted upper and lower lips, decreased interlabial gap, and increased nasolabial angle. On the basis of the data obtained it could be concluded that the break of the habit allow skeleto-dental and soft tissue improvement, and early intervention of thumb sucking are essential to re-establish the adequate growth and development potential.
\end{abstract}

\section{INTRODUCTION}

Non-nutritive sucking behaviors like digit or pacifier sucking in infants and young children are mainly derived from the physiologic need to satisfy the urge for nutrients, contact and security ${ }^{(1,2)}$. However, once the habit persist for some reasons and become chronic, their resolution is difficult $^{(3,5)}$. Continued sucking habit may cause inadequacies on the

\footnotetext{
* Assistant Professor of Orthodontics, Faculty of Dentistry, Tanta University.

** Assistant Professor of Pedodontics, Faculty of Dentistry, Tanta University.
} 
Egyptian

Orthodontic Journal

stomatognathic system, due to the misbalance of the forces that naturally take action on the oral cavity ${ }^{(6-10)}$ causing abnormalities in dentition and occlusion $^{(11)}$. Children who have continued sucking habit may present anterior open bite, posterior cross bite, upper incisor protrusion, crowding of the mandibular incisors and abnormal skeletal pattern ${ }^{(12-15)}$. The amount of dento-alveolar skeletal deformation is related to the frequency, duration, direction and intensity of the habit ${ }^{(11)}$.

The simple removal of the habit until the beginning of the mixed dentition may cause a spontaneous correction of the resulting occlusal abnormalities $^{(17,18)}$. This compensatory dento-alveolar mechanism is characterized by a relative growth of the dento-alveolar height of the maxilla and mandible during mixed dentition, and by reducing posterior dento-alveolar height in permanent dentition ${ }^{(19)}$.

Skeletal changes persist even after the removal of the parafunctional habit, the typical skeletal pattern of open bite also remains in subjects who showed an apparently spontaneous regression without any orthodontic treatment ${ }^{(20,21)}$. Degon et al. ${ }^{(22)}$ pointed that not all children, who have sucking habits broken are provided with spontaneous correction and may need some professional interventional procedure. The early intervention on the orofacial musculature dysfunction, which is provided by breaking sucking habits associated with myofunctional therapy, may facilitate the normal craniofacial growth and development ${ }^{(23-25)}$.

However, if the child continued the finger sucking habit after pubertal growth, permanent effects on occlusion are anticipated and self correction might not occur ${ }^{(26)}$. Possible factors leading to retention of this malocclusion include tongue thrusting habit, hyperactive oral muscles and abnormal swallow, and if not corrected this will lead to relapse after finishing orthodontic treatment ${ }^{(27)}$.

Many authors (28-30) have included an evaluation of soft tissue changes in relation to the changes in the underlying hard tissue, and found positive relationships, while an analysis of profile changes in thumb suckers, occurring as a part of orthodontic treatment has not been within the scope of previous studies. 
Egyptian

Orthodontic Journal

The aim of this study was to evaluate the profile changes in patients with thumb sucking after breaking the habit and correction of the established malocclusion using palatal crib habit breaking appliance and fixed orthodontic treatment.

\section{MATERIALS \& METHODS}

The sample consisted of 15 female subjects between the age of 8-10 years, from the Pedodontic and Orthodontic Departments, Faculty of Dentistry, Tanta University. Subjects were eligible for this study if they had a non nutritive sucking, irrespective of the molar relationship. Eligibility was assessed by patient history, parent's history and oral examination. Clinical examination as well as the usual diagnostic aids, diagnostic study models, panoramic cephalometric radiographs, extra and intra-oral photographs, were obtained before and after active treatment.

For all cases, working models were poured in stone and were used for fabrication of palatal crib appliance made for the study.

\section{Treatment plane:}

1- Habit breaking appliance to stop ongoing thumb sucking habit.

2- Fixed orthodontic appliance at the upper and lower arches ( 2 X 4) to level and align the teeth.

3- Midline and vertical seating elastics to idealize the occlusion.

4- Retainer placed after appliance removal.

\section{Design of palatal crib appliance:}

The appliance was made of two bands on the upper first permanent molars with a metal framework extended palatally up to the mesial surface of the second primary molar. The metal framework is made from $0.9 \mathrm{~mm}$ stainless steel wire and consisted of finger cribs facing down at the anterior part of the appliance and an extension of the metal frame facing up at its posterior part. The metal framework was soldered via an extended wire to the palatal surface of the molar bands. The appliance was to be cemented on the first permanent molars using glass-ionomer cement after checking for gingival impingement (Figs. 1). 

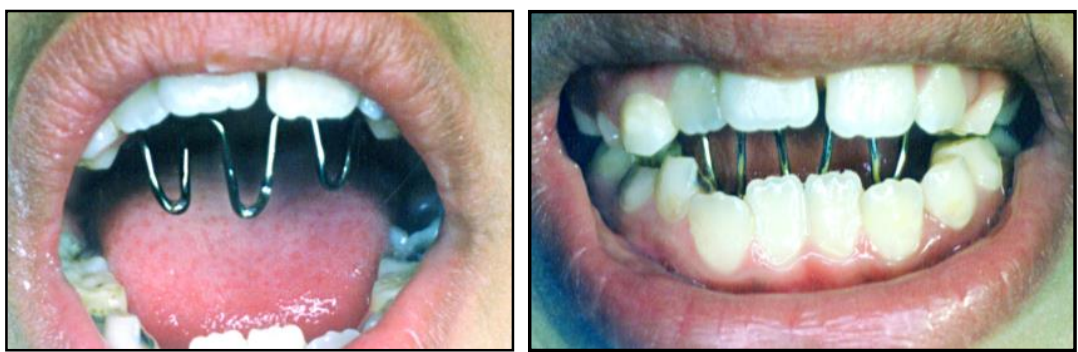

Fig (1) Appliance used in the study, after insertion.

After insertion of the appliances, the participants were examined every 4 weeks, until the habit was eliminated. The habit breaking appliance should remain in place for at least 6 months after habit cessation to ensure that the habit had truly stopped. After that the fixed orthodontic appliance(stainless steel edgewise brackets) on the incisors was bonded to correct the remaining malocclusion .
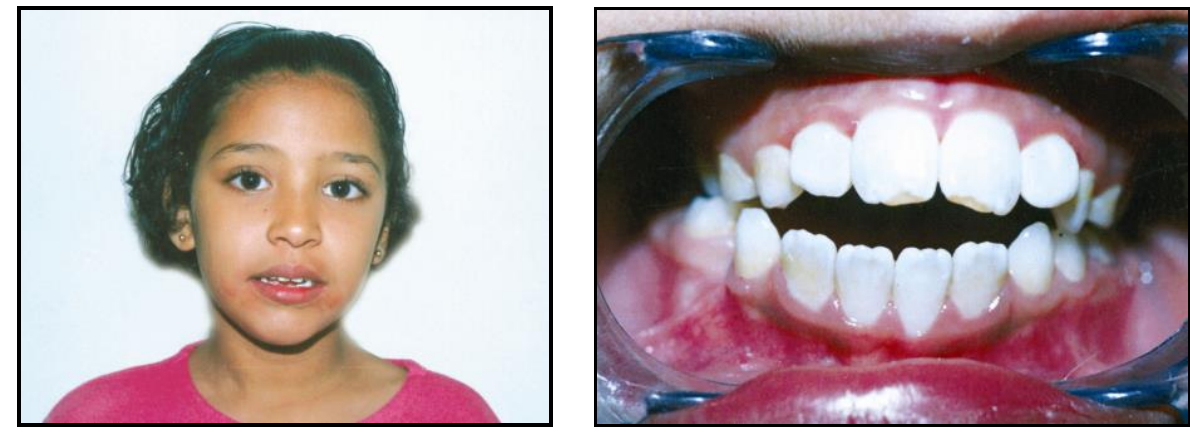

Fig. (2) Patient with anterior open bite from thumb sucking habit.
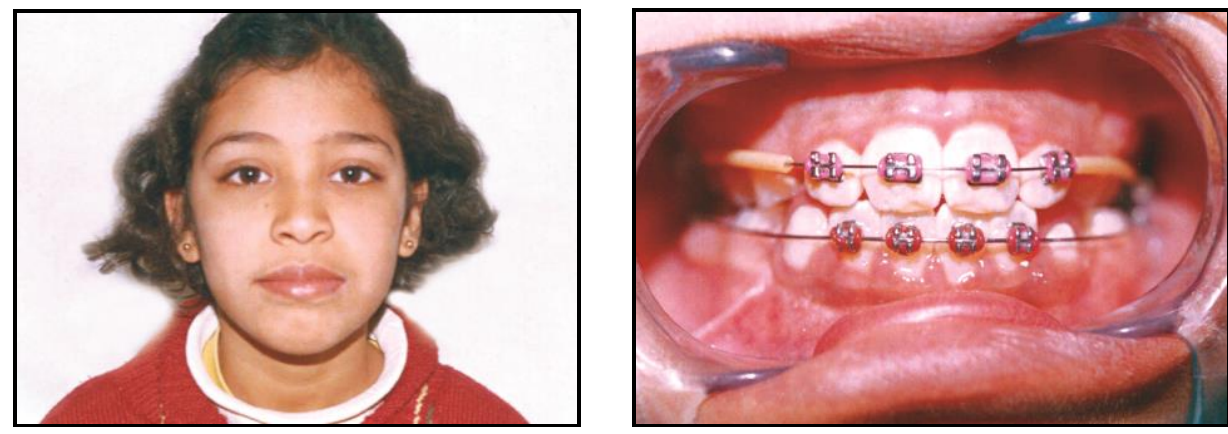

Fig. (3) The same patient after treatment.

Volume $34-$ December 2008 
Standardized lateral cephalograms were traced on acetate paper with $0.5 \mathrm{~mm}$ diameter lead pencil by the investigators, the cephalometric landmarks, lines and planes were identified and traced.

\section{Cephalometric Landmarks ( Fig. 4 ):}

S: Sella, midpoint of the sella turcica.

$\mathbf{N}$ : Nasion, junction of the frontal and nasal bones at the naso-frontal suture.

A: A Point, deepest point in the concavity of the anterior maxilla between the anterior nasal spine and the alveolar crest.

B: B Point, deepest point in the concavity of the anterior mandible between the alveolar crest and pogonion.

Cd: Condylion, most postero-superior point of the mid-planed contour of the mandibular condyle.

Gn: Gnathion, most antero-inferior point on the bony chin, located by bisecting mandibular and facial planes.

ANS: Anterior Nasal Spine, anterior limit of the floor of the nose, at the tip of the anterior nasal spine.

Me: Menton, most inferior point on the bony chin.

Po:Porion, most superior point of the bony external auditory meatus.

Or:Orbitale, most inferior point on the infra-orbital margin .

\section{Cephalometric Measurements( Fig. 4):}

SNA: angle formed by sella-nasion and A point

SNB: angle formed by sella-nasion and B point

ANB: difference between SNA and SNB

Upper incisor to $\mathbf{S N}$ : angle formed by the intersection of maxillary central incisor and $\mathrm{SN}$ line.

Lower incisor to MP: angle formed by the intersection of mandibular central incisor and mandibular plane. 
Y-axis angle: formed by intersection of sella-gnathion and the Frankfurt horizontal plane (line from porion to orbitale).

Inter-incisal angle: formed by the intersection of the maxillary central incisor and the mandibular central incisor

Md Length: measure the length of the mandible from condyloin to gnathion

Max length: measure the length of the maxilla from condylion to A point.

Lower anterior face height (LAFH): measures the length from ANS to menton.

Nasolabial angle: angle formed by intersection of a columella tangent and an upper lip tangent.

Upper Lip to E Line: distance in mm between the upper lip and the E line (Esthetic line that connect the tip of the nose to the anterior point on soft tissue chin)

Lower Lip to E Line: distance in $\mathrm{mm}$ between the lower lip and the $\mathrm{E}$ line.

Interlabial gap: the vertical distances between the upper and lower lips.

Over jet: Overjet was measured from the incisal edge of the most labially positioned maxillary central incisor to the labial surface of the mandibular central incisor.

Overbite: was taken as the vertical measurement of the overlap of the incisal edge of the maxillary central incisor and the incisal edge of the mandibular central incisor.

Occlusion assessment: was recorded using Angle's molar classification.

Changes in cephalometric measurements after treatment were recorded and reconfirmed.

\section{Reliability:}

A paired t-test was used to detect the differences between 2 different tracings that were performed on a different occasions by the investigators. There was no significant difference between any of the variables using t-test at significant level of 0.05 . 


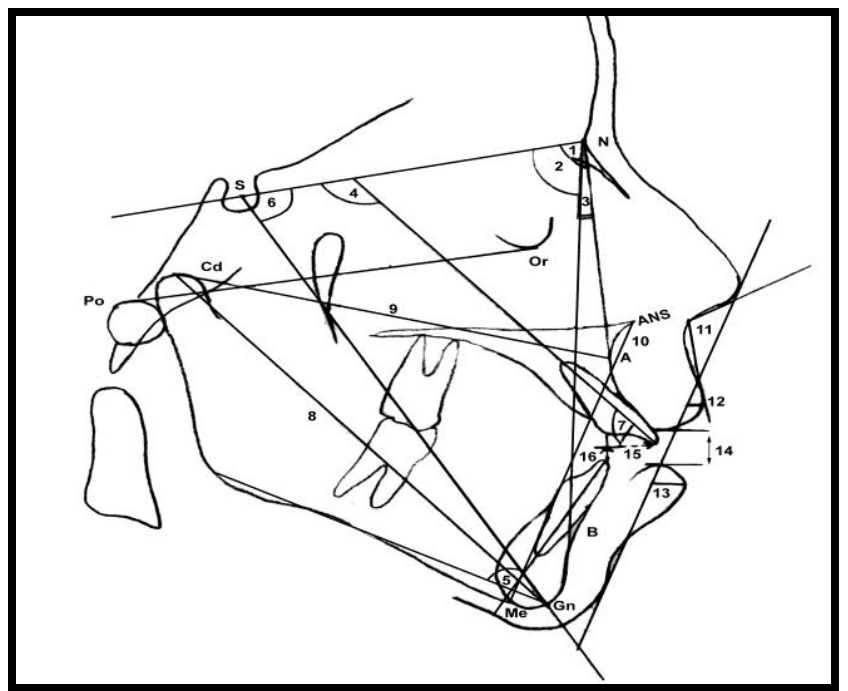

Fig. (4): Cephalometric Measurements: 1 SNA,2 SNB,3 ANB,4 Upper incisor to SN: angle,5 Lower incisor to MP angle,6 Y axis angle,7 Inter-incisal angle,8 MdLength,9 Max unit length,10 Lower anterior face height,11 Nasolabial angle,12 Upper Lip to E Line,13 Lower Lip to E Line,14 Interlabial gap,15 Over jet,16 Overbite.

\section{Statistical analysis:}

The collected data were organized, tabulated and statistically analyzed using SPSS software statistical computer package version 12 program. Paired t- tests were used to compare before and after treatment for the subjects. The results were assessed at a level of significance $5 \%$, and presented in Tables $(1,2,3)$ and Figures $(5,6,7)$.

\section{RESULTS}

- Treatment duration was 16-18 months. The palatal crib appliance successfully arrested the thumb-sucking habit. All subjects had a tongue thrust habit due to the negative overbite. The anterior extended metal crib of the appliance helped in controlling the forward tongue posture.

- Speech and pattern of swallowing were affected during the first few days of wearing the appliance as reported by parents, after which the child was able to adapt to the appliance.

- The child was able to discontinue the sucking habit after 2:3 visits and showed no relapse and return to the habit during the treatment period. 
- All patients had class II on both sides before starting treatment and, at the end of treatment, they had class I on both sides.

\section{Angular measurements (Table 1, Fig.5):}

SNA angle showed significant decrease after treatment, while the mean SNB showed an increased but not reach to significant level, with the resultant a decrease in the ANB significantly.

There were highly significant decrease in proclination of the upper and lower incisor as indicated by a significant reduction in upper incisor to SN plane, lower incisor to MP, and the inter-incisor angle. A significant decrease of the $\mathrm{Y}$ - axis angle was observed, while a significant increase of Nasolabial angle was obtained.

\section{Linear measurements: (Table 2, Fig. 6):}

The mandibular length showed significant increase, while the maxillary length showed non significant decrease of the mean after treatment, and LAFH showed significant decrease after treatment.

\section{Soft tissue measurements (Table 3, Fig. 7):}

There were significant differences between all other linear parameters, $\mathrm{U}$ lip to $\mathrm{E}$ line, $\mathrm{L}$ lip to $\mathrm{E}$ line, inter labial gap, overjet were significantly decrease while the overbite showed significant increase.

Table (1): Descriptive and comparative statistics of angular measurements:

\begin{tabular}{||l|c|c|c|c||}
\hline \multirow{2}{*}{} & Before & After & \multicolumn{2}{c|}{ Paired t-test } \\
\cline { 2 - 5 } & Mean \pm SD & Mean \pm SD & t & P-value \\
\hline SNB & $82.367 \pm 1.043$ & $80.500 \pm 0.779$ & 7.897 & $0.000^{*}$ \\
\hline ANB & $76.967 \pm 0.812$ & $77.067 \pm 1.348$ & -0.350 & 0.731 \\
\hline$\perp_{\text {to }}$ SN & $5.400 \pm 0.930$ & $3.433 \pm 1.400$ & 5.271 & $0.000^{*}$ \\
\hline $\boldsymbol{T}^{\text {to }} \mathbf{M P}$ & $113.267 \pm 3.474$ & $104.300 \pm 3.005$ & 15.342 & $0.000^{*}$ \\
\hline Y-axis angle & $97.900 \pm 1.526$ & $91.607 \pm 1.048$ & 17.660 & $0.000^{*}$ \\
\hline$\perp_{\text {to }} \boldsymbol{T}$ angle & $72.367 \pm 1.797$ & $69.300 \pm 1.821$ & 9.025 & $0.000^{*}$ \\
\hline Nasolabial angle & $107.133 \pm 3.067$ & $123.433 \pm 2.397$ & -24.247 & $0.000^{*}$ \\
\hline \hline
\end{tabular}

Significant at $5 \%$. 


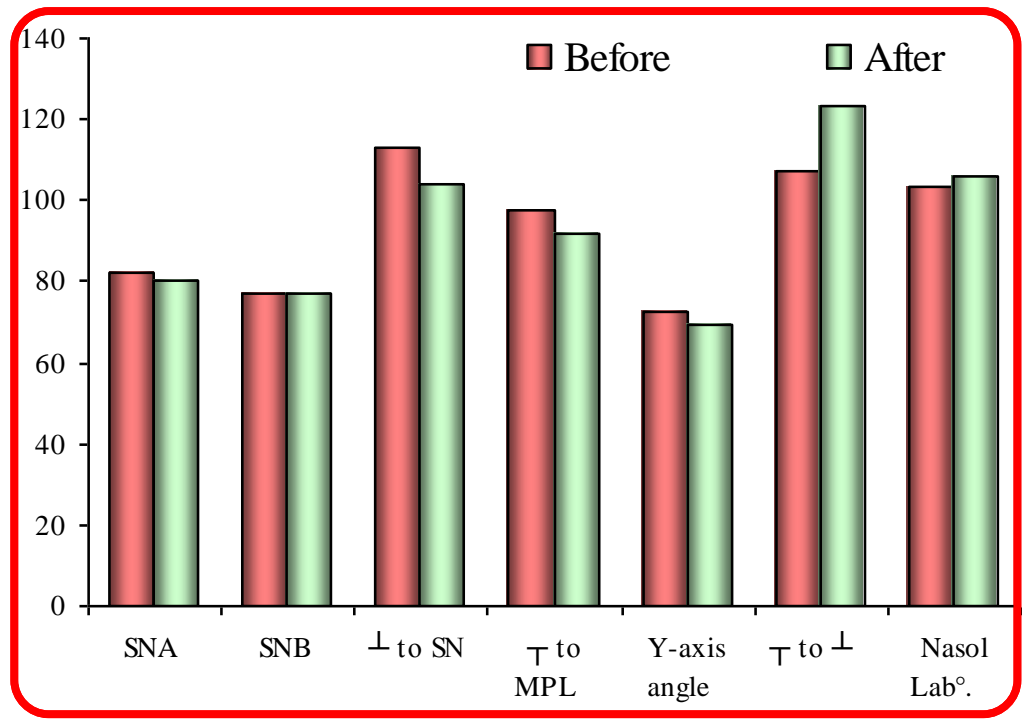

Fig (5): Mean changes in angular measurements.

Table (2): Descriptive and comparative statistics of linear measurements:

\begin{tabular}{|l|c|c|c|c||}
\hline \multirow{2}{*}{} & Before & After & \multicolumn{2}{c|}{ Paired t-test } \\
\cline { 2 - 5 } & Mean \pm SD & Mean \pm SD & t & P-value \\
\hline Md. L & $106.533 \pm 0.834$ & $108.367 \pm 1.093$ & 0.332 & $0.000^{*}$ \\
\hline Max. L & $88.333 \pm 0.957$ & $86.667 \pm 1.029$ & 4.194 & 0.745 \\
\hline LAFH & $70.800 \pm 2.455$ & $68.633 \pm 2.496$ & 10.564 & $0.000^{*}$ \\
\hline
\end{tabular}

Significant at 5\%.

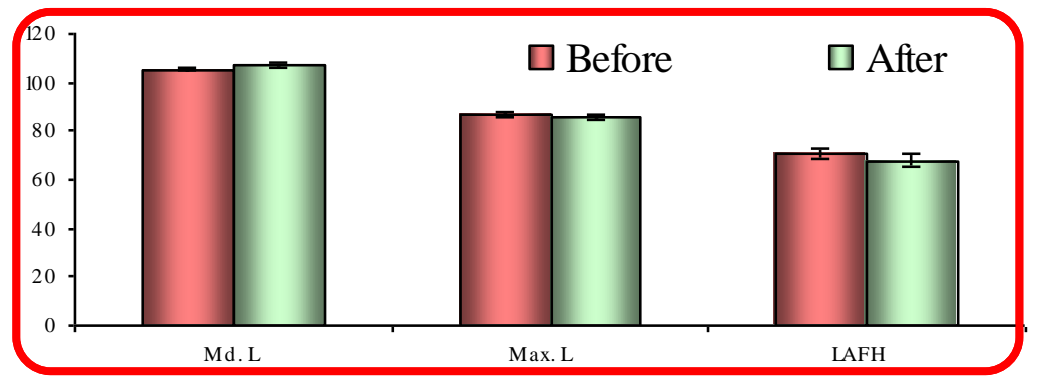

Fig (6) Mean changes in linear measurements. 
Egyptian

Orthodontic Journal

Table (3) Descriptive and comparative statistics of soft tissue measurements.

\begin{tabular}{||l|c|c|c|c||}
\hline \multirow{2}{*}{} & Before & After & \multicolumn{2}{c|}{ Paired t-test } \\
\cline { 2 - 5 } & Mean \pm SD & Mean \pm SD & t & P-value \\
\hline U lip to E & $1.667 \pm 1.543$ & $0.800 \pm 1.049$ & 3.166 & $0.007^{*}$ \\
\hline L lip to E & $4.600 \pm 2.261$ & $2.200 \pm 1.131$ & 5.015 & $0.000^{*}$ \\
\hline Inter lip gap & $6.733 \pm 2.492$ & $2.033 \pm 0.935$ & 6.814 & $0.000^{*}$ \\
\hline Over jet & $6.467 \pm 1.060$ & $2.000 \pm 0.423$ & 16.584 & $0.000^{*}$ \\
\hline Over bite & $-1.400 \pm 1.056$ & $2.667 \pm 0.488$ & -12.880 & $0.000^{*}$ \\
\hline
\end{tabular}

Significant at $5 \%$.

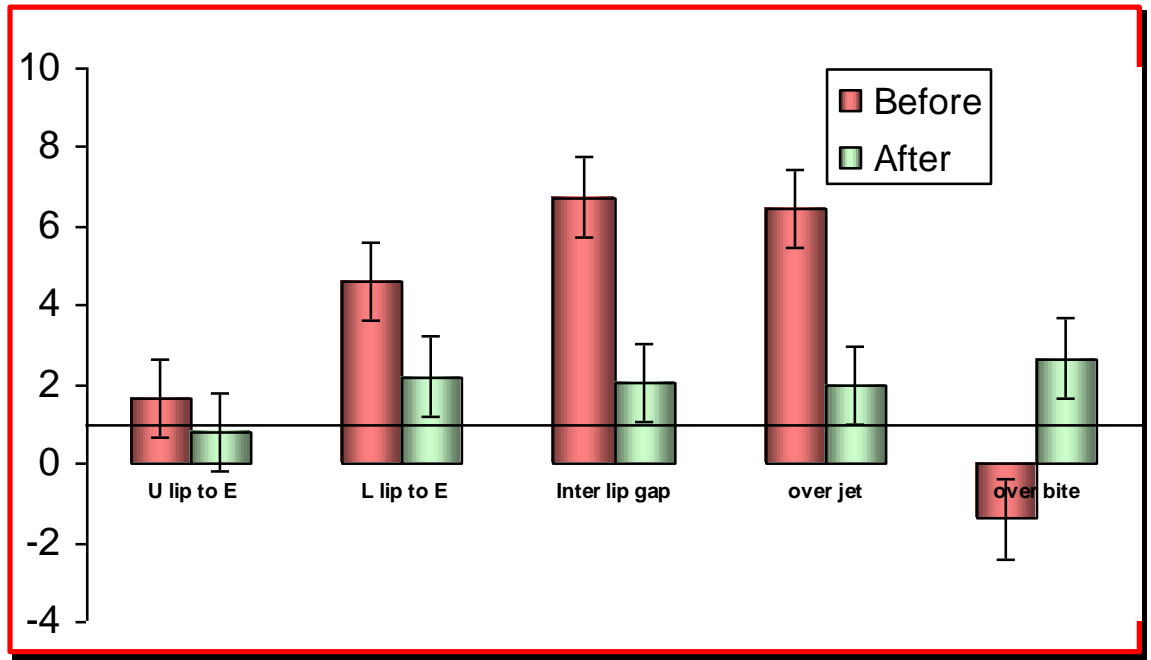

\section{DISCUSION}

Thumb sucking habits have a well established reputation, both within the orthodontic profession and among patients for causing malocclusion. While it is easy for orthodontists and patients to recognize that a relationship between digit sucking habits and malocclusion may exist, the precise changes of soft tissue morphology require clarification. 
Because of improvement of facial esthetics has become one of the main objectives of orthodontic treatment, the present study was concerned with evaluation of soft tissue profile effects secondary to treatment of thumb sucking habit.

The ages of subjects in this study were between 8 and 10 years, as previous recommendations ${ }^{(31-33)}$ suggested that it is better to intervene with appliance after the permanent teeth start to erupt. Also, it was not expected that children in this selected age group would stop a prolonged oral habit on their own without intervention ${ }^{(34)}$.

The result of this study showed that, the thumb sucking habit was broken after 7-8 weeks. To ensure that the child will not return to the habit, the fixed habit breaking appliances was left for 6 months after the child stopped the habit, as recommended by Proffit ${ }^{(33)}$, Greenleaf and Mink $^{(35)}$. They found that the duration of treatment is an important factor that affects two different outcomes, namely, the success of habit-breaking and the improvement in malocclusion.

The pre-treatment cephalometric analysis showed that thumb suckers were associated with cephalometric differences after treatment. A number of significant differences were observed which can reasonably attributed to the relief of thumb sucking.

After treatment, significant decrease in maxillary protraction (SNA angle) was obtained, since the palatal crib helps in relief the direct pressure on the anterior region of palate, which may reach to $4.52 \mathrm{~kg}{ }^{(36)}$ and considered larger than normal tongue pressure $1.57 \mathrm{~kg}{ }^{(37)}$ causing correction of protracted maxilla.

SNB angle was increased after treatment but not reach to significant value. It seems likely that the effect of the habits on the lower incisors and mandibular position will depend on exactly how the digit is positioned and the action of the tongue during the sucking process ${ }^{(38)}$. Since the SNB anlgle before treatment was nearer to the normal value at that time (76.9 and 77.3 respectively), so such changes may be attributed to the normal growth increments (1: $2 \mathrm{~mm} /$ year) at the same time ${ }^{(39)}$.

Consequently the ANB angle was increased with significant difference due to the significant decrease of SNA angle. 
Although the forward growth that is encouraged by the long-term force generated during thumb sucking was removed, the maxillary length was found to be increased after treatment but the difference was not reach to a significant level. This result may contradict to the significant decrease in SNA angle as it was suggested that 1 degree change in SNA angle is equivalent to a $1 \mathrm{~mm}$ linear change in the position of point $\mathrm{A}$ during the mixed dentition growth. ${ }^{(39)}$ This may be due to the fact that A point is influenced by the degree of proclination of the maxillary incisors. So after correction of maxillary incisor position and lingual tipping of the crown, the position of point A would be displaced labially, this may participate in the increase of maxillary length.

On the other hand, the mandibular length was significantly increased after treatment. This may be due to the fact that in normal condition, the effective length of the mandible increases approximately $2: 3 \mathrm{~mm}$ per year, and in the present study the results were not demonstrated any changes as regard the mandibular growth due to thumb sucking, so the growth increments occurred as normal.

Post treatment results revealed that Y-axis angle and LAFH were statistically significant decreased, indicating anterior rotation of the mandible with expected effects of vertical control in molar extrusion, which was not measured in the present study. This is in accordance with Brenchley (40) who found that during treatment, thumb suckers demonstrated rotation of the maxillary plane, with the anterior region moving in a downward direction and the posterior region moving in an upward direction and LAFH was decreased. So favorable changes may occur as the habit was interrupted or ceased which assisted the correction of the vertical changes due to thumb-sucking. The facial hyperdivergency in addition to thumb sucking habit is considered as risk factors in the development of open bite and poor treatment outcome ${ }^{(41)}$.

After treatment all subjects had reduction in lower incisor to MP and upper incisor to $\mathrm{SN}$ as reflected in an increase in inter-incisal angle. Since the retraction of upper and lower incisors correlated with upper and lower lips retraction ${ }^{(29)}$, and the incisors were used as a predictive model for change in the lips. So retroclination of upper and lower incisors led to retraction of upper and lower lip, and consequently decrease in the $\mathrm{U}$ lip 
to $\mathrm{E}$ line and L Lip to E line and with closure of lips and significant decreased in inter-labial gap. This is consistent with what was reported by Cozza et $\mathrm{al}^{(42)}$. They studied the effects of the modified quad- helix with palatal crib appliance after breaking the thumb- sucking habit.

In current study almost all subjects had some degree of open bite which led to a degree of tongue thrust and in turn can cause the mandibular incisors to procline. Cephalometric results showed that open bite reduction was statistically significant. This reduction may be related to soft tissue changes; tongue position and lip pressure. The tongue's adequate resting position would eliminate physical forces and would contribute for the re-arrangement of the oral cavity forces, consequently allow correction of the occlusion. ${ }^{(43)}$ In addition to the soft tissue factor, both the increase in the dentoalveolar development during treatment of anterior open bite cases ${ }^{(44)}$, and extrusion of anterior incisors with vertical elastics were participated in the correction of open bite.

The overjet relation had a significant decrease at the end of treatment. This change was occurred due to the increase in the interincisal angle caused by the concomitant decrease in the $\perp$ to $\mathrm{SN}$ and T to MP .This result contradicts that obtained by Villa Cineros ${ }^{(45)}$ and Usumez et $\mathrm{al}^{(46)}$, as they revealed minimal overjet reduction. This may be due to the fact that they used fixed palatal crib and myofunctional trainer appliances respectively, and the overjet is self corrected after breaking the habit.

Nasolabial angle was significantly increased after treatment as it was influenced by the posture of the upper lip and upper incisors proclination, so it was increased as a result of decreasing upper incisor to SN angle ${ }^{(47)}$.

Literatures reports showed the effects of palatal crib and fixed orthodontic appliances in thumb suckers in an attempt to understand the possible changes in different aspects of the face imposed limitation. They apply a removable or fixed habit breaking appliances, without fixed orthodontic braces to level and align the teeth, thus the outcomes were not sufficient to discuss with the present results.

Previous authers found a complex interaction between the dentition, the bony structures, and the perioral soft tissue profile., Therefore, early 
Egyptian

Orthodontic Journal

intervention of thumb sucking can re-establish the adequate growing and development potential, and the break of habits allow skeleto-dental and soft tissue improvement.

\section{CONCLUSION}

Treatment with a palatal crib and fixed orthodontic appliance therapy resulted in the following changes:

1- Statistically significant decrease in maxillary protraction and mandibular hyperdivergency

2- Retrusion and extrusion of the incisors as well as increase in overbite and decrease in overjet with statistically significant differences

3- The lower anterior facial height was decreased and the mandibular length was increased significantly after treatment.

4- Soft tissues improvement were occurred in the form of retracted lips, decreased inter-labial gap, and increased nasolabial angle, with statistical significant differences.

\section{REFERENCES}

1- Johnson ED and Larson Be. Thumb-sucking: literature review. ASDC J Dent Child 1993; 60:385 -391.

2- Kamiyama K, Manyanagi H, Saitou S, Igarashi K and Tsukada N. Questionnaire on the habits of nursery school children. Jpn J Pediatr Dent 1975; 13:36-41. (in Japanese).

3- Kwata TT, Najagawa H, Ohtani S, Kushima F, Ishida N and Takimoto K. Experimental study on abnormal habits and malocclusion-Acquirement of finger habits. Jpn Orthod Soc 1971 30:18-24. (in Japanese).

4- Traisman AS and Traisman HS. Thumb and finger sucking: A study of 2,650 infants and children .J Pediatr. 1958 ; 52:566-572.

5- Rosemarie A and Norman V. Why we can't afford to ignore prolonged digit sucking contemporary pediatrics. 2001; 6:61. 
6- Cayley AS, Tindall AP, Sampson WJ and Butcher AR. Electropalatographic and cephalometric assessment of myofunctional therapy in open-bite subjects. Orthod J. 2000; $16: 23-33$.

7- Zardetto CG, Rodrigues CR, Stefani FM. Effects of different pacifiers on the primary dentition and oral myofunctional structures of preschool children. Pediatr.Dent. 2002; 24 : 552-560.

8- Charchut SW, Allred EN and Needleman HL. The effects of infant feeding patterns on the occlusion of the primary dentition. ASDC $\mathbf{J}$ Dent Child. 2003; 70 :197-203.

9- Souza NB and Vasconcelos TCA. Influência de hábitos orais como fator etiologico de mordida aberta anterior. Revista CEFAC- Atualização, Cientifica em Fonoaudiologia, São Paulo. 2003; 5 : 235-240.

10- Bertoldi P, Felcio M and Matsumoto MA. Effect of the early intervention of oral habits on the development of dental occlusion Pró-Fono Revista de Atualização, Cientifica, Barueri, 2005 ; 17 : 37-44.

11- Nord F. The reader comments .Am J Dent Assoc. 1992; 64:872.

12- Garreto AL. Orofacial myofunctional disorders related to malocclusion. Int J Orofacial Myology. 2001; 27: 44-54.

13- Degan VV and Puppin-rontani RM. Terapia Miofuncional e hábitos orais infantis.Revista CEFAC-Atualização, Cientifica em Fonoaudiologia. São Paulo. $2004 ; 6$ : 396-404.

14- Linge LB. Patient characteristics and treatment variables associated with apical root resorption during orthodontic treatment. Am J orthod Dentofacial Orthop. 1991; 99 :35- 39

15- Warren J, Bishara SE, Steinbock KL, Yonezu T and Nowak AJ. Effects of oral habits' duration on dental characteristics in the primary dentition .J Am Dent. Assoc 2001;132: 1685- 1693

16- Kelly J, Sanchez M and Vankirkl. An assessment of the occlusion of the teeth of children Washington, De National Center For Health statistics, Us public health service, DHEW publication No (HRA) 74, 1612. 
17- Chevitarese AB, Dell Vall D and Moreria TC. Prevalence of malocclusion in 4-6 years old Brazilian children .J Clin Pediatr Dent 2002 ;27:81- 85.

18-Siqueira VCV, Negreiro PE and Benites WRC .Aetiologia da mordida aberta na dentadura deciduas .RGO $2002 ; 50: 99-104$.

19- Betzenberger D, Ruf S and Pancherz H. The compensatory mechanism in high-angle malocclusion: a comparison of subjects in the mixed and permanent dentition .Angle Orhod 1999; 69:27 32.

20- Warren JJ and Bishara SE. Duration of nutritive and nonnutritive sucking behaviors and their effects on the dental arches in the primary dentition .Am J Orthod Dentofacial Orthop 2002;121: 347-356.

21- Klocke A, Nanda RS and Kahl- Nieke B. Anterior open bite in the deciduous dentition: longitudinal follow-up and craniofacial growth consideration. Am J Orthod Dentofacial Orthop 2002; 122:353-358.

22- Degan VV, Boni RC and Almeida RC. Idade adequada para remoção de chupeta e/ou mamadeira, na faixa etária de 4 a 6 anos. J. Orthop -Orthod Ped. Dent 2001; 3: 5-16.

23- Haruki T, Kishi K and Zimmerman J. The importance of orofacial myofunctional therapy in pediatric dentistry: Reports of two cases. ASDC J Dent Child1999; 84:103- 109.

24- Jefferson Y. Orthodontic diagnosis in young children: beyond dental occlusions. Gen Dent 2003; 51: 104-111.

25- Pascal HHM, Van lieshout P H, BOSE A and Namasivayam AK. Physiological effects of an 8-week mechanically aided resistance facial exercise program. Int.J. Orofacial Myology $2002 ; 28: 49-73$.

26-Larsson E and Ronnerman A. Clinical crowen length in 9-11 and 13 year old children with and without finger sucking habit. $\mathrm{Br} \mathrm{J}$ of Orthod., 1981; 8:171-173.

27- Turner S, Nattrass C and Sandy JR. The role of soft tissues in the etiology of malocclusion. Dent. Update, 1997, 24:209-214.

28- Zylinski CG, Nanda R S and Kapila S. Analysis of soft tissue facial profile in white males. Am J Orthod Dentofial Orthop 1992; 101:514-518. 
Egyptian

Orthodontic Journal

29- Blanchette MR, Nanda RS, Currier GF, Ghash J and Nanda SK. A longitudinal cephalometric study of the soft tissue profile profile of short and long face syndrome from 7 to 17 years. Am J Orthod Dentofial Orthop 1992; 101:514-518.

30- Halazonetis DJ. Morphometric correlation between facial soft tissue profile shape and skeletal patter in children and adolescents. Am J Orthod Dentofacial Orthoped.2007; 132:450-457.

31- Gellin ME. Digital sucking and tongue thrusting in children Dent clinic of North Am.1978; 22:603-619.

32- Haskell BS and Mink JR. An aid to stop thumb sucking: The blue grass appliance. Ped Dent.1991; 13:83-85.

33- Proffit WR and Field HW. Contemporary Orthodontics, $3^{\text {rd }}$ edition. St Louis, Mo: Mosby 2000 .

34- Larsson E. Treatment of children with prolonged dummy or fingersucking habit. Eur J Orthod. 1988; 10: 244-248.

35- Greenleaf S and Mink J. A retrospective study of the use the blue grass appliance in the cessation of thumb habits: Ped. Dent. 2003; 25:587-590.

36- Yokota R, Mishiro M, Abe T, Miyalce A, Shiina N, Sueishi K and Yamagachi $\mathrm{H}$. Pressure on Anterior Region of palate during thumb suekmg. Bull to lcyo Ent Coll. 2007; 48: 57-66.

37- Mishiro M, Jiyake A, Abe T, Yokota R, Sueishi K, Yamaguchi H. Measurements of the tongue pressures on the anterior region of the palate in children-About the difference arising from the occlusion and the existence of the tongue habit. J Tokyo Orthod Soc. 2004; 14: 153-162. (in Japanese).

38- Moore MB and McDonald JPA. Cephalometric Evaluation of Patients Presenting with Persistent Digit Sucking Habits. Br J Orthod 1997; $24: 17-23$.

39- McNamara JA and Brudon WL. Orthodontic and orthopedic treatment in the mixed dention. Needham Press , inc 1993.chapter 2. 
Egyptian

Orthodontic Journal

40- Brenchley ML. Is digit sucking of significance? Br Dent J.1991; 171: 357- 362.

41- Cozza P, Baccetti T, Franchi L, Mucedero M and Polimeni A. Sucking habits and facial hyperdivergency as risk factors for anterior open bite in the mixed dention.Am J Orthod Dentofacial Orthop; 2005; 128:517-519.

42- Cozza P, Baccetti T, Franchi L and McNamara JA. Treatment effects of a modified quad-helix in patients with dentoskeletal open bites. Am J Orthod Dentofacial Orthop. 2006; 129:734-739.

43- Dogan VV and Puppin-Rontani RM. Removal of sucking habits and myofunctional therapy: establishing swallowing and tongue rest position. Pro-Fono Revista de Atualizaçào Cientific, 2005; 17: 375-382.

44- Lopez DR, Gavito GI, Little RM, Wallen TR and Joondeph DR. Anterior open bite malocclusion: a longitudinal 10- year post retention evaluation of orthodontically treated patients. Am J Orthod. 1985; $87: 175-186$

45- Villa NL and Cisneros G J. Changes in the dentition secondary to palatal crib therapy in digit- suckers. A preliminary study. Pediatr Dent. 1997; 19: 323-326 .

46- Usumez S, Uysal T, Sari Z, Basciftici FA, Karaman AI and Guray E. The effects of early pre-orthodontic trainer treatment on class II division I patients.Angl Orthod 2004; 74:605-609.

47- Legan HL, and Burstone CJ. Soft tissue cephalometric analysis for orthognathic surgery. J Oral Surg, 1980; 38:744-751. 